\title{
Analisis Efektivitas Pemupukan Menggunakan Pesawat Udara Di Kebun Batang Gading Pt. Satya Kisma Usaha Kabupaten Bungo
}

\author{
Analysis Of The Effectiveness Of The Fertilizer Using Aircraft In The Garden Bar Ivory \\ Pt. Satya Kisma Usaha District Bungo \\ Feri Misrianto, Widuri Susilawati, Fikriman \\ Program Studi Agribisnis, Fakultas Pertanian Universitas Muara Bungo \\ e-mail : Ferimisrianto@gmail.com
}

\begin{abstract}
Abstrak
Penelitian ini bertujuan untuk mendeskripsikan proses serta tingkat efektivitas pemupukan kelapa sawit menggunakan pesawat. Hasil penelitian menunjukkan bahwa proses pemupukan kelapa sawit menggunakan pesawat di Kebun Batang Gading PT. Satya Kisma Usaha memiliki tingkat efektivitas yang tinggi dan sangat cocok digunakan untuk lahan yang arealnya berbukit dan curam serta prosedur selama pemupukan berdasarkan pedoman pemupukan yang sudah disusun sedemikian rupa mulai dari proses persiapan sampai proses pelaksanaan. Namun demikian pada proses pemupukan menggunakan pesawat tersebut tidak semua jenis pupuk yang bisa diaplikasikan karena sebelum ditaburkan semua jenis pupuk majemuk di aduk menjadi satu. jadi, perusahaan tetap melaksanakan pemupukan manual seperti pupuk Borat, hal ini dikarenakan pupuk Borat tidak bisa dicampur dengan jenis pupuk lainnya dan kadar dosis yang tersedia dalam pupuk Borat pun sangat tinggi dibandingkan pupuk lainnya. Meskipun tingkat efektivitas pemupukan menggunakan pesawat tinggi namun, selama pelaksanaan masih terdapat kekurangan seperti landasan Airstrip yang masih jalan tanah sehingga diwaktu musim hujan proses pemupukan sedikit terganggu karena landasannya licin serta stok pupuk yang ada di Bin hanya ditutupi menggunakan terpal plastik.
\end{abstract}

Kata Kunci: Efektivitas, Pemupukan dan Pesawat

\begin{abstract}
this research study aims to describe the process as well as the effectiveness of fertilizing palm using the aircraft. The results showed that the fertilization process of palm oil using aircraft in Ivory Trunk Gardens PT. Kisma Satya Enterprises have a high level of effectiveness and is suitable for land area is hilly and steep and fertilization procedures during fertilization based guidelines that are constructed in such a way from the process of preparation to the implementation process. However, the process of fertilization using the plane is not all type of fertilizer that can be applied since before sprinkled all kinds of compound fertilizer in the mix together. so, the company still had to manually like manure fertilization Borat, Borat fertilizer because it can not be mixed with other fertilizer types and levels of doses available in Borat fertilizer is very high compared to other fertilizers. Although the effectiveness of fertilizer use high air however, there is still a shortage during the execution of such a foundation Airstrip is still a dirt road so at a time when the rainy season fertilization process a little disturbed because of the slippery runway and existing fertilizer stocks in the bin simply covered using plastic sheeting.
\end{abstract}

Keywords : Effectiveness, The Fertilizer and Aircraft

\section{PENDAHULUAN}

Perkebunan kelapa sawit mempunyai prospek yang cerah untuk dikembangkan sebagai sumber devisa negara, perluasan kesempatan kerja, kelestarian sumber daya alam serta sebagai wahana pembangunan. Minyak kelapa sawit (Crude Palm Oil/CPO) mempunyai prospek pemasaran sangat tinggi disamping harganya yang kompetitif. Permintaan dunia terhadap CPO lebih cepat meningkat daripada penawaran (Departemen Pertanian, 2006).

Komoditas perkebunan merupakan andalan bagi pendapatan nasional dan devisa negara Indonesia, yang dapat dilihat dari nilai ekspor komoditas perkebunan, pada Tahun 2013 total ekspor perkebunan mencapai US\$ 29,476 milyar atau setara dengan Rp. 353,713 triliun (asumsi 1 US\$=Rp.12.000). Kontribusi sub sektor perkebunan terhadap perekonomian 
nasional semakin meningkat dan diharapkan dapat memperkokoh pembangunan perkebunan secara menyeluruh. Indonesia merupakan salah satu produsen kelapa sawit yang terus berkembang. Luas areal perkebunan kelapa sawit di Indonesia pada tahun 2015 seluas 11.444 .808 ha dan produksinya sebesar 30.948.931 ton (Ditjenbun, 2016).

Permintaan produk dari kelapa sawit meningkat sejalan dengan meningkatnya konsumsi minyak sawit dunia. Upaya dalam meningkatkan poduksi terus dilakukan baik melalui perluasan areal maupun dalam hal perbaikan teknis budidaya. Pemeliharaan merupakan salah satu faktor yang perlu mendapatkan perhatian dalam budidaya kelapa sawit. Pemeliharaan pada perkebunan kelapa sawit meliputi sensus pohon, pemeliharaan jalan, pengendalian hama dan penyakit, penunasan pelepah daun, dan pemupukan. Pemupukan merupakan faktor yang sangat penting untuk meningkatkan produksi. Biaya yang dikeluarkan untuk pemupukan berkisar $40-60 \%$ dari biaya pemeliharaan tanaman secara keseluruhan atau sekitar $20 \%$ dari total biaya produksi. Hasil penelitian menunjukkan pemupukan mutlak dilakukan karena secara nyata bisa meningkatkan produksi dan tetap menjaga stabilitas tanaman. (Sinar Mas Agribusiness Research and Technology, 2003).

Pemupukan dapat dilakukan dengan tiga cara antara lain pemupukan manual, pemupukan secara mekanis dengan Fertilizer Spreader, dan pemupukan dengan pesawat. Pemupukan manual menghasilkan mutu yang beragam dan membutuhkan tenaga kerja yang banyak. Hal ini merupakan masalah yang terjadi setiap tahun. Pemupukan dengan Fertilizer Spreader hanya dapat digunakan untuk wilayah datar saja sedangkan untuk wilayah berbukit seperti di Kabupaten Bungo ini tidak bisa digunakan. Dengan adanya permasalahan seperti itu maka salah satu alternatif untuk mencapai pemupukan yang lebih baik dan layak yaitu pemupukan menggunakan pesawat yang lebih rata dan tepat sasaran (Sinar Mas Agribusiness Research and Technology, 2003).

Adapun rumusan masalah dari penelitian ini adalah. "Bagaimana efektivitas pemupukan menggunakan pesawat di Kebun Batang Gading PT.Satya Kisma Usaha Kabupaten Bungo.

Adapun tujuan dari penelitian ini adalah : "Untuk mengetahui efektivitas pemupukan menggunakan pesawat di Kebun Batang Gading PT. Satya Kisma Usaha Kabupaten Bungo."

Pelaksanaan penelitian ini diharapkan dapat memberikan manfaat yaitu: (1) Sebagai masukan bagi pihak yang terkait dalam pengembangan teknologi usahatani kelapa sawit sehingga sasaran yang dituju tercapai. (2) Untuk meningkatkan dan memperluas wawasan dalam menganalisa masalah yang dijumpai di lapangan serta untuk studi pembanding antara teori dan praktek di lapangan khususnya didalam proses pemupukan menggunakan pesawat ini. (3) Sebagai bahan informasi awal bagi para peneliti selanjutnya yang berminat untuk melanjutkan penelitian ini.

\section{METODE}

Penelitian ini dilaksanakan di Kebun Batang Gading PT Satya Kisma Usaha Kabupaten Bungo yang merupakan satu-satunya perusahaan Perkebunan Kelapa Sawit di Kabupaten Bungo yang telah melakukan pemupukan menggunakan pesawat, dan penelitian dilaksanakan tanggal 15 Desember 2016 sampai 15 Januari 2017.

Jenis dan Sumber data yang diperoleh berupa data primer dan sekunder. Data primer merupakan data yang langsung diperoleh dari petani responden dan data sekunder adalah 
data penunjang yang diperoleh melalui

dokumen maupun laporan tertulis dan

informasi dari instansi terkait.

Jenis data yang dihimpun dalam penelitian ini meliputi data kualitatif yaitu data yang diperoleh secara deskriptif berupa informasi lisan maupun tertulis

Dasar penelitian yang digunakan dalam penelitian ini adalah studi kasus, yaitu dilakukan secara intensif, dalam, mendetail dan komperehensif terhadap objek penelitian guna menjawab permasalahan yang diteliti karena penelitian memiliki beberapa batasan sehubungan dengan permasalahan yang diangkat mengenai pemupukan menggunakan pesawat, maka yang menjadi pengamatan dalam penelitian ini adalah tingkat efektifitas pemupukan.

PT. Satya Kisma Usaha merupakan target objek penelitian karena perusahaan tersebut satu-satunya perusahaan yang sudah menggunakan pesawat dalam proses pemupukan.

Teknik pengumpulan data dilakukan melalui dua tahap antara lain: (1) dilakukan melalui studi kepustakaan, yaitu dengan mengumpulkan data-data atau literaturliteratur baik dari buku cetak maupun penulisan penulisan terdahulu yang ada kaitannya dengan rencana penelitian ini. (2) dilakukan pengumpulan data baik primer maupun sekunder melalui wawancara terstruktur dengan menggunakan daftar pertanyaan serta melakukan observasi dan survei langsung di lapangan maupun lembaga-lembaga atau instasi terkait.

Untuk tujuan penelitian dijelaskan dengan cara deskriptif sesuai dengan keadaan yang ada dilapangan tentang efektifitas pemupukan menggunakan pesawat di daerah penelitian di Kebun Batang Gading PT. Satya Kisma Usaha kabupaten Bungo. Metode
Analisis Deskriptif merupakan cara merumuskan dan menafsirkan data yang ada sehingga memberikan gambaran yang jelas mengenai perusahaan secara umum. (Fred R. David, 2006 ).

\section{HASIL DAN PEMBAHASAN}

Berdasarkan hasil wawancara dan observasi yang dilakukan di Kebun Batang Gading PT Satya Kisma Usaha. Maka adapun hasil penelitian yang didapatkan dapat digambarkan sebagai berikut :

Tujuan dari penelitian ini adalah untuk mengetahui tingkat efektivitas pemupukan menggunakan pesawat. Berdasarkan hasil data yang diperoleh dari responden atau perusahaan di lapangan maka dapat diketahui sejarah pemupukan menggunakan pesawat, faktor efektivitas, serta perbandingan pemupukan menggunakan pesawat dengan pemupukan lainnya.

\section{Sejarah Pemupukan}

Pemupukan melalui udara menggunakan pesawat dimulai pilot projectnya sejak Tahun 1996 oleh PT.SMART Coorporation di daerah Riau. Project ini bekerja sama dengan perusahaan New Zealand Super Air Ltd yang telah berpengalaman dalam hal aerial manuring dan penggunaan GPS, yang dibentuk menjadi PT.Sinar Mas Super Air. Awal Maret 1999. PT. Sinar Mas Super Air memulai dengan 3 Pesawat yang dioperasikan di Riau.

PT. Sinarmas Super Air merupakan sebuah perusahaan yang bergerak dibidang jasa yang dibentuk PT. SMART dikhususkan untuk melakukan pemupukan keseluruh perkebunan yang dimilikinya. Jadi, seluruh perkebunan Sinar Mas wajib untuk menggunakan pesawat dalam pemupukan kelapa sawit karena dengan menggunakan pesawat dapat memaksimalkan hasil 
produksi dan juga dapat meminimalkan tingkat kehilangan pupuk yang disebabkan faktor manusia dan faktor lainnya.

Ada dua pesawat yang digunakan dalam pemupukan ini yang pertama Pesawat yang digunakan merupakan pesawat capung atau pesawat fletcher FU 24-950 dengan kapasitas muatan $1.275 \mathrm{~kg}$ kemudian pesawat capung jenis Fokker dengan kapasitas muatan lebih besar dari pesawat jenis Flatcher muatan maksimal 1,5 Ton dibantu dengan truk pengaduk pupuk atau yang disebut truk Manitou berfungsi untuk memasukkan muatan pupuk kedalam pesawat sekaligus untuk menentukan jumlah kapasitas pupuk yang akan ditaburkan.

Untuk lebih jelasnya dapat dilihat pada tabel berikut :

\begin{tabular}{|c|c|c|}
\hline & Spesifikasi Alat & Keterangan \\
\hline 1 & $\begin{array}{l}\text { Jenis Pesawat } \\
\text { Terbang } \\
\text { - } \quad \text { Kapasitas } \\
\quad \text { muatan pupuk } \\
\text { - } \quad \text { Kecepatan } \\
\text { - } \quad \text { Hopper } \\
\text { - } \quad \text { Veighing } \\
\quad \text { Gauge }\end{array}$ & $\begin{array}{l}\text { Fletcher FU 24- } \\
950 \\
1.275 \mathrm{~kg} \\
167-212 \\
\mathrm{~km} / \mathrm{jam} \\
\text { Didepan } \\
\text { Cockpit } \\
\text { Alat penunjuk } \\
\text { berat muatan } \\
\text { pupuk }\end{array}$ \\
\hline 2 & $\begin{array}{l}\text { Jenis Pesawat } \\
\text { Terbang } \\
\text { - Kapasitas } \\
\text { muatan } \\
\text { - Kecepatan } \\
\text { - Hopper } \\
\text { - Veighing } \\
\text { Gauge } \\
\text { Truk Mixer/ } \\
\text { Manitou } \\
\text { - Model } \\
\text { - Type }\end{array}$ & $\begin{array}{l}\text { Fokker F 39- } \\
950 \\
1.500 \mathrm{~kg} \\
167-220 \\
\mathrm{~km} / \mathrm{jam} \\
\text { Dibelakang } \\
\text { Cockpit } \\
\text { Alat penunjuk } \\
\text { berat muatan } \\
\text { Untuk } \\
\text { mencampur } \\
\text { pupuk }\end{array}$ \\
\hline
\end{tabular}

\begin{tabular}{|c|c|c|}
\hline & & $\begin{array}{l}\text { Massey } \\
\text { Ferguzon } \\
\text { MF-240 4WD }\end{array}$ \\
\hline 3 & $\begin{array}{ll}\text { Truk } & \text { Mixer/ } \\
\text { Manitou } & \\
\text { - } & \text { Model } \\
\text { - } & \text { Type }\end{array}$ & $\begin{array}{l}\text { Untuk } \\
\text { mencampur } \\
\text { pupuk } \\
\text { Massey } \\
\text { Ferguzon } \\
\text { MF-240 4WD }\end{array}$ \\
\hline
\end{tabular}

Sumber : Sinar Mas Agribusiness Research and Technology 2003

Dalam program ini perusahaan terus menerus berupaya untuk meningkatkan kinerjanya dengan menggunakan tenaga yang berpengalaman dan profesional serta dituntut bisa menguasai bahasa inggris seperti pilot, enginer, dan lain sebagainya. Untuk pilot sendiri perusahaan mendatangkan tenaga kerja dari luar negeri dengan sistem kontrak, hal ini dilakukan untuk memaksimalkan kinerja pemupukan agar pemupukan jauh lebih efektif.

Setelah sukses diterapkannnya pemupukan menggunakan pesawat di Riau kemudian projectnya terus berkembang ke berbagai perkebunan Sinar Mas seperti Kalimantan, Papua, Sulawesi, dan berbagai perkebunan lainnya termasuk di PT. Satya Kisma Usaha.

Mulai Tahun 2009 awal Februari, PT. Satya Kisma Usaha mulai melaksanakan program pemupukan menggunakan pesawat dengan tujuan dapat meningkatkan hasil produktifitas serta kesejahteraan perusahaan melalui tingkat aksesibilitas terhadap informasi,dan teknologi.

Pihak manajemen PT. Satya Kisma Ir. Suripto mangatakan bahwa pemupukan menggunakan pesawat ini sudah dilakukan dari Tahun 2009 sampai sekarang. Tidak hanya perkebunan inti, perkebunan rakyat yang berada dibawah naungan perusahaan pun juga sudah menggunakan pesawat. 
Untuk mengoptimalkan proses produksi terutama disektor pemupukan sampai saat ini Kebun Batang Gading PT. Satya Kisma Usaha terus menggunakan jasa pesawat Hal ini menunjukkan bahwa pemupukan menggunakan pesawat memberikan hasil yang positif bagi perusahaan.

\section{Deskripsi Proses Pemupukan}

Sebelum dilaksanakannya pemupukan menggunakan pesawat pihak kebun terlebih dahulu harus mempersiapkan segala hal seperti luas areal, jumlah pokok sawit serta jumlah dosis yang dibutuhkan tanaman kelapa sawit. Dalam pembuatan rekomendasi pemupukan, hasil analisis kandungan unsur hara di daun merupakan salah satu pertimbangan yang sangat menentukan. Faktor yang mempengaruhi keakuratan analisis kandungan hara daun di laboratorium sangat ditentukan oleh proses pengambilannya di lapangan.

LSU atau leaf sampling unit bisa merupakan gabungan dari beberapa blok sesuai dengan kesamaan. Diambil satu blok sebagai blok contoh, dengan syarat yang mewakili. Bisa juga merupakan gabungan dari beberapa blok untuk memenuhi luasan minimal 16 Ha. Dalam pengambilan sampel daun (LSU) terlebih dahulu harus mengetahui Ha Statement / data pengambilan sampel daun ini untuk memudahkan dalam pengambilan contoh daun. Ha statement merupakan data wilayah atau area yang akan dilakukan pengambilan sampel daun.

Di PT. Satya Kisma Usaha untuk satu LSU diperlukan \pm 40 pohon contoh. Sistem pembagian / pengambilannya menggunakan sistem ancak tersebar merata. Misalkan pada blok 13 merupakan blok besar yang terbagi menjadi 5 subblok kecil yaitu 13A, 13B, 13C, 13D, dan 13E dengan kata lain setiap satu subblok kecih harus di ambil 8 pohon contoh daun

Setelah semua selesai dilaksanakan maka hasil LSU dikirim ke PT. SMARTRI untuk diteliti dilabor sehingga dapat diketahui jenis pupuk dan dosis yang dibutuhkan tanaman. PT. SMARTRI ini merupakan salah satu cabang perusahaan PT. SMART yang bergerak disektor laboratorium khusus untuk menentukan jumlah dosis yang direkomendasikan ke pihak perkebunan PT. Satya Kisma Usaha.

Setelah pihak perkebunan memperoleh rekomendasi jenis, dan jumlah dosis pupuk dari PT. SMARTRI kemudian data tersebut dikirim ke PT. Sinar Mas Super Air untuk dipelajari dan disesuaikan dengan jumlah Run atau jumlah pusingan pesawat diudara dalam satu kali penerbangan.

Namun, dengan adanya pemupukan pesawat bukan berarti pemupukan manual ditiadakan hal ini disebabkan tidak semua jenis pupuk dapat di aplikasikan dengan pesawat seperti pupuk Borat yang kadar dosisnya jauh lebih tinggi dibandingkan pupuk lain dan tidak bisa digabung atau dicampur dengan pupuk majemuk lainnya seperti Urea, Mop, TSP, dan jenis pupuk lainnya.

Landasan pesawat yang berukuran panjang 900-1000 meter dan Lebar 40-60 meter. Pada daerah runway selebar 18 meter harus dipadatkan dengan baik dan permukaan runway dibuat miring untuk menghindari genangan air ketika hujan. Lokasi landasan dipilih berdasarkan syaratsyarat teknik landasan serta berada ditengah areal yang akan dipupuk.

Pada ujung landasan ditempatkan bin pupuk yang digunakan untuk menimbun pupuk yang telah di aduk ataupun untuk mengaduk menggunaakan loader, bin pupu ini terbuat dari beton dengan dinding pembatas dan plat lantai berbentuk segitiga. 
Peta kebun dengan dosis sesuai rekomendasi, diperoleh dari Riset Libo. Peta ini dibuat untuk mengelompokkan dosis pupuk yang sama dalam satu kebun agar pelaksanaan dalam pemupukan dapat lebih mudah.

Untuk pelaksanaan pemupukan dengan pesawat tahap-tahap yang harus dilakukan adalah persiapan-persiapan awal, penyediaan pupuk, penebaran pupuk,dan evaluasi mutu penyebaran pupuk.

Persiapan-persiapan awal yang dilakukan adalah penyiapan sarana prasarana pendukung guna memperlancar kegiatan pemupukan di Airstrip. Contoh memasang rambu-rambu agar kegiatan yang ada disekitar Airstrip hanya untuk kegiatan pemupukan pesawat.

Setelah tahap persiapan awal dilakukan ,maka operasional aplikasi aerial manuring dimulai dari pengiriman pupuk dari Gudang central ke Bin pupuk di Airstrip. Hal-hal yang harus dipersiapkan untuk organisasi pupuk dari Gudang Central ke Bin pesawat adalah sbb: (1) 2 unit Dum truck kapasitas 6 ton standbay untuk langsir pupuk dari gudang central ke bin landasan. (2) 2 orang supervisi (mandor/pengawas) yaitu satu orang digudang central dan satu orang di Bin pupuk. Mandor harus permanen tidak boleh diganti-ganti. (3) Total pupuk yang harus disediakan di bin perhari adalah 70 ton (standbay).

Sebelum pemupukan dimulai, pada block yang rencana hendak dipupuk harus dipasang paper trap dengan ukuran kertas $1 \mathrm{~m}$ x $1 \mathrm{~m}$. Papertrap ini diletakkan di pasar pikul mengikuti jalur lintas terbang berfungsi untuk mengetahui apakah pupuk yang ditaburkan oleh pesawat sampai ke block yang di rekomendasikan. Setelah semua jenis pupuk tercampur sesuai dengan dosis yang telah ditentukan, maka pemupukan sudah dapat dimulai. Pengisian pupuk ke hopper dilakukan oleh loader. Jumlah yang dimuat biasanya 1 ton untuk satu kali penerbangan. Berdasarkan program dari GPS akan diketahui berapa kali pilot harus menerbangkan pupuk pada hamparan yang sudah ditentukan. Aplikasi pemupukan dalam 1 hari dapat mencapai 60-80 ton.

Jumlah tersebut hanya dapat dimaksimalkan jika faktor penghambatnya sedikit seperti cuaca hujan yang menyebabkan jalan lintasan pesawat licin, dan kendala kerusakan pesawat yang butuh perbaikan dan teknisi yang memakan waktu cukup lama jika tingkat kerusakan nya tinggi.

\section{Hasil Pemupukan}

\section{Perbandingan Pemupukan Manual Dengan Pesawat}

Data yang diperoleh dari hasil penelitian menunjukkan bahwa efektivitas pemupukan menggunakan pesawat sangat berpengaruh bagi perusahaan terutama dari segi hasil produksi yang secara nyata mampu mendongkrak tingkat produksi dua kali lipat dibandingkan pemupukan manual.

Hal ini dikarenakan karena prosedur sistem pemupukan menggunakan pesawat sudah disusun dan dibentuk sedemikian rupa sehingga pupuk yang dikirim dari gudang benar-benar sampai ke tanaman dan tingkat kehilangan serta kecurangan yang terjadi dapat atasi dengan mudah.

Hasil wawancara yang dilakukan peneliti kepada pimpinan perusahaan menjelaskan bahwa, pemupukan manual yang dilakukan selama ini masih jauh dari kata efektif bahkan dapat diperkirakan pupuk yang sampai kelapangan hanya berkisar 50\% dari total yang dikirim dari gudang sedangkan yang 50\% nya lagi hilang, hal ini dikarenakan susahnya pengawasan yang dilakukan dalam proses pemupukan manual ini. Sebenarnya pemupukan manual bagus, jika pemupukan dilakukan sesuai dengan prosedur dimana 
pupuk yang diaplikasikan oleh pekerja langsung diterima oleh tanaman contohnya dengan sistem tanam. Hanya sulitnya pengawasan yang dilakukan dilapangan membuat pemupukan ini tidak efektif.

Dalam proses pemupukan manual ini untuk satu orangnya dijatah sebanyak lima karung pupuk isi $50 \mathrm{~kg}$ atau $250 \mathrm{~kg} /$ orang dengan bayaran yang diterima sebanyak $1 \mathrm{HK}$ atau Rp77.000. berarti dengan jumlah pupuk sebanyak itu berarti satu orang pekerja harus mampu menyelesaikan dengan jumlah areal lebih kurang $1 \mathrm{Ha}$ per hari. Jika, pekerja yang bekerja dalam satu hari berjumlah 100 orang berarti realisasi pemupukan mencapai 2,5 Ton/hari dengan jumlah bayaran sebanyak Rp 7.700.000. tentunya dengan hasil sebanyak ini sangat lah efektif dari segi waktu dan sangat efisien dari segi biaya. Namun faktanya bertolak belakang dengan apa yang terjadi dilapangan.

Satu orang pekerja yang dijatah untuk pemupukan per harinya 5 karung kenyataannya paling banyak yang direalisasikan paling banyak hanya 3 karung berarti yang 2 karungnya lagi hilang atau dibuang kesungai. Jadi hal ini lah yang menjadi motivasi perusahaan untuk memilih pemupukan menggunakan pesawat karena secara nyata menunjukkan hasil yang jauh signifikan dibandingkan pemupukan manual.

Pihak perusahaan mengatakan, perusahaan lebih baik memilih alternatif yang tepat seperti pemupukan menggunakan pesawat daripada pemupukan manual yang mengakibatkan perusahaan rugi dari segi upah pekerja dan pupuk yang dibeli dengan harga yang mahal ternyata tidak sampai ke tenaman.

Pemupukan menggunakan pesawat ini merupakan alternatif yang tepat dibandingkan pemupukan lainnya apalagi dengan kondisi lahan yang berbukit, meskipun biayanya jauh lebih mahal mencapai 1.100.000 / Ton atau $1.100 / \mathrm{kg}$. Selain biaya tersebut perusahaan juga harus mengeluarkan biaya lain seperti biaya tenaga kerja tukang muat, mobil langsir pupuk, serta biaya tenaga kerja di BIN .

Untuk tukang muat pupuk satu ton dibayar Rp 22.000 diatas basis,artinya setelah tukang muat mendapatkan total basis dengan jumlah 20 Ton maka diatas jumlah tersebut satu ton nya dibayar Rp 22.000. dan untuk mobil langsir pupuk dari gudang ke airstrip satu tonnya dibayar Rp 15.000. serta tenaga kerja yang berada di Airstrip dibayar 1,5 Hk atau Rp 115.500 dengan jumlah tenaga kerja sebanya lima orang.Jadi dalam satu hari pemupukan perusahaan mengeluarkan biaya mencapai Rp 2.000.000

Biaya yang dikeluarkan ini tentunya sebanding dengan hasil yang diperoleh perusahaan dan pupuk yang dialokasikan benar-benar sampai tujuan.

\section{Perbandingan Pemupukan Dengan Cara Mekanis}

Pemupukan dengan cara mekanis atau biasa disebut fertililizer speader adalah proses pemupukan tanaman kelapa sawit dengan cara sistem tabur Aplikasi pemupukan yang dilakukan menghasilkan mutu yang lebih baik seperti sebaran pupuknya lebih merata dan seragam.

Pada pemupukan manual seringkali masih ada pupuk yang ditabur dalam bentuk bongkahan. Pupuk yang disebar dengan Fertilizer Spreader semuanya tidak ada yang berbentuk bongkahan karena semuanya sudah melewati proses penyaringan. Hal ini akan mengakibatkan tanaman lebih efektif lagi dalam menyerap unsur hara. Pemupukan manual sebaran pupuknya terdapat di piringan luar (batas antara piringan dengan rumpukan pelepah).

Pada pemupukan secara mekanis dengan Fertilizer Spreader sebaran pupuknya merata di semua tempat, hal ini akan memungkinkan untuk tudung akar lebih leluasa lagi dalam menyerap unsur hara. 
Seringkali pada pemupukan secara mekanis dengan Fertilizer Spreader ada pupuk yang tersebar di batang, hal ini akan efektif apabila dilakukan sebelum datangnya hujan karena pupuk yang ada di batang akan dibawa oleh air hujan sampai ke bagian tudung akar. Losses atau kehilangan hara pada pemupukan manual lebih besar dibandingkan dengan pemupukan dengan Fertilizer Spreader karena pada pemupukan manual digunakan tenaga kerja yang cukup banyak sekitar 15-20 orang setiap satu kali pemupukan sehingga memungkinkan untuk terjadi losses atau kehilangan hara. Kebutuhan tenaga kerja dalam pemupukan secara mekanis lebih sedikit hanya membutuhkan 3 orang yang rinciannya 1 orang sebagai operator traktor, dan 2 orang sebagai helper pada Fertilizer Spreader.Helper bertugas untuk memasukan pupuk ke dalam hopper yang berfungsi sebagai tempat menampung pupuk.

Basis kerja operator $25 \mathrm{ha} / \mathrm{HK}$, dan bila operator mencapai basis, maka operator traktor mendapat premi sebesar Rp 2 000,-/ha. Setelah digunakan alat tersebut harus dicuci. Premi untuk mencuci alat Rp 2 000,-. Basis untuk helper 25 ha/2 orang. Premi yang diberikan apabila mencapai basis sebesar $\mathrm{Rp}$ 1 500,- /orang. Biaya pemupukan dengan menggunakan Fertilizer Spreader lebih murah dilihat dari aspek tenaga kerja karena dengan sedikitnya tenaga kerja akan

mengurangi kebutuhan perumahan dan biaya karyawan yang lainnya.

Efektivitas pupuk yang lebih baik akan mengakibatkan kebutuhan pupuk berkurang. Karena dengan adanya ketepatan dalam pemupukan tanaman maka tanaman akan memiliki ketersediaan unsur hara yang cukup yang mengakibatkan akan mengurangi pemupukan pada periode selanjutnya. Selain itu juga, traktor dapat dioptimalkan penggunaannya untuk kegiatan di luar pemupukan seperti transportasi dan membantu dalam kegiatan semprot.

Berdasarkan penjelasan di atas maka dapat diambil kesimpulan bahwa pemupukan secara mekanis lebih efektif terutama dari segi waktu biaya dan tenaga kerja, sama halnya dengan pemupukan menggunakan pesawat. Hanya saja pemupukan secara mekanis atau fertilizer speader ini terdapat kekurangan antara lain : perlu ada biaya investasi untuk pembelian traktor dan Fertilizer Spreader hanya dapat diterapkan pada areal datar sampai landai dengan kemiringan lereng 0-50, serta terjadi pemadatan tanah pada jalan pikul, Selain itu juga pertumbuhan gulma dan kompetisi penyerapan hara dengan gulma lebih terjadi dibandingkan dengan pemupukan pesawat, karena pada pemupukan dengan menggunakan Fertilizer Spreader pupuk yang disebar lebih merata ke semua permukaan tanah yang memungkinkan gulma yang hidup disana akan lebih cepat untuk hidup.

Sedangkan untuk daerah Kabupaten Bungo khususnya di Kebun Batang Gading PT Satya Kisma Usaha kondisi areal perkebunannya hapir $70 \%$ bergelombang, berbukit, dan berbukit curam. Jadi pemupukan secara mekanis ini hanya bisa digunakan di areal datar dan tidak dapat digunakan di areal yang berbukit.

\section{Faktor Efektivitas Pemupukan Pesawat}

\section{Tepat Waktu}

Waktu pelaksanaan dalam proses pemupukan menggunakan pesawat dilakukan dua periode dalam setahun yaitu periode pertama antara bulan Januari sampai Februari, dan periode kedua bulan Juli sampai Agustus atau dilaksanakan pada waktu periode yang telah ditentukan apabila ada perubahan cuaca atau iklim seperti cuaca hujan berkepanjangan dan kemarau panjang.

Kebun Batang Gading PT Satya Kisma Usaha mempunya luas lahan 2.794,24 ha dengan total kebutuhan dosis dan jenis 
pupuk yang berbeda. Selang waktu antara aplikasi pupuk sama jenis, selang waktu antara pupuk yang berbeda dan selang waktu antara aplikasi pupuk dengan periode pemupukan tentunya menjadi perhatian utama perusahaan. Karena aplikasi pemupukan dalam waktu yang sama akan menghasilkan hasil yang seragam juga.

Pemupukan pesawat dikatakan tepat waktu karena waktu pemupukan relatif jauh lebih singkat dan jauh lebih efektif, dengan lama pemupukan paling lama 2 bulan dengan jumlah ribuan ton pupuk yang diaplikasikan ke masing - masing divisi.

Berdasarkan hasil wawancara dengan pimpinan perusahaan, Estate Manager Batang Gading PT Satya Kisma Usaha menyatakan bahwa pemupukan yang dilakukan menggunakan pesawat sangat efektif terutama dari segi waktu, dimana jumlah pupuk yang banyak dan luas lahan ribuan hektar dapat diselesaikan dalam waktu yang relatif lebih cepat dan pemupukan lebih serasi.

\begin{tabular}{|c|c|c|c|c|}
\hline $\begin{array}{c}\text { N } \\
\text { O }\end{array}$ & $\begin{array}{c}\text { Divis } \\
\text { i }\end{array}$ & $\begin{array}{c}\text { Jumlah } \\
\text { Pupuk } \\
\text { (Ton) }\end{array}$ & $\begin{array}{c}\text { Pemup } \\
\text { ukan } \\
\text { Pesaw } \\
\text { at }\end{array}$ & $\begin{array}{c}\text { Pemupuk } \\
\text { an } \\
\text { Manual }\end{array}$ \\
\hline 1 & I & 444.050 & 8 hari & 4 bulan \\
\hline 2 & II & 364.000 & 6 hari & 4 bulan \\
\hline 3 & III & 335.000 & 7 hari & 3,5 bulan \\
\hline 4 & IV & 34.000 & 4 jam & 1 bulan \\
\hline 5 & V & 148.600 & 13 hari & 3 bulan \\
\hline 6 & VI & 250.000 & 10 hari & 3 bulan \\
\hline 7 & VII & 125.600 & 6 hari & 2,5 bulan \\
\hline
\end{tabular}

Sumber : Kantor Besar PT Satya Kisma Usaha.

Dari tabel di atas dijelaskan bahwa pemupukan menggunakan pesawat jauh lebih efektif dari segi waktu dibandingkan dengan pemupukan manual yang membutuhkan waktu yang sangat lama sehingga dalam satu periode pemupukan menjadi tidak seragam atau tidak serasi. Pemupukan menggunakan pesawat dapat menyelesaikan pemupukan lebih cepat dengan jumlah pupuk ribuan ton, hanya saja untuk divisi 5 proses pemupukan agak lama dikarenakan adanya gangguan hujan yang menyebabkan pemupukan kurang efektif, walaupun demikian pemupukan menggunakan pesawat tetap jauh lebih cepat dibandingkan pemupukan manual. 2. Tepat Cara

Tepat cara adalah dimana pupuk ditempatkan atau diaplikasikan di lapangan dengan cara menabur pupuk dengan cara yang baik dan benar. Pertimbangannya adalah agar tanaman dapat menyerap secara maksimal, meminimalkan kehilangan hara pupuk, meminimalkan kompetensi dengan gulma dan sebagainya.

Dengan adanya aplikasi pemupukan menggunakan pesawat menjadi pilihan yang tepat bagi perusahaan karena pemupukan melalui udara ini dapat menghasilkan hasil yang optimal. Pemupukan dengan cara ditabur ini dilakukan keseluruh lahan yang akan dipupuk dan dapat langsung diterima oleh daun tanaman.

Seperti yang dikemukan oleh Lingga, (2002) pemupukan melalui daun mempunyai banyak kelebihan dibandingkan dengan pupuk akar yaitu (1) Pupuk daun dapat memberi hara sesuai kebutuhan tanaman.(2) Pupuk yang diberikan ke tanah tidak seluruhnya sampai ke akar tanaman. (3) Kelarutan pupuk daun lebih baik dibandingkan pupuk akar. (4) Pengaruh kekurangan hara berlangsung lebih cepat dibandingkan pupuk akar.(6)Pemberiannya jauh lebih merata.(7) Kepekatannya dapat diatur sesuai pertumbuhan tanaman.

\section{Tepat Sasaran}

Sasaran atau tujuan proses pemupukan menggunakan pesawat ini adalah untuk menjaga tingkat stabilitas tanaman, meningkatkan hasil produksi, menambah unsur hara yang hilang atau kurang dipasok oleh tanaman yang diperlukan untuk pertumbuhan yang optimal. 
Pemupukan menggunakan pesawat ini dikatakan tepat sasaran karena pupuk yang diaplikasikan di lapangan benar - benar diterima oleh tanaman serta tingkat penyerapannya jauh lebih tinggi karena pemupukan langsung di terima melalui daun tanpa harus berkompetisi dengan gulma yang ada di sekitar piringan pokok sawit. Dan tingkat kehilangan yang disebabkan oleh faktor manusia dan faktor lainnya seperti yang terdapat di pemupukan manual dapat teratasi sehingga pemupukan jauh lebih efektif.

Tepat sasaran merupakan bagian dari faktor efektivitas yang berarti ada efeknya, manfaatnya, dan dapat membawa hasil dari suatu usaha yang sudah dilakukan. Seperti yang didefenisikan dalam Kamus Besar Bahasa Indonesia (KBBI) bahwa efektivitas adalah sesuatu yang memiliki pengaruh atau akibat yang ditimbulkan, manjur, membawa hasil, dan, merupakan keberhasilan dari suatu usaha atau tindakan.

Dalam hal ini efektivitas atau sasaran pemupukan dapat dilihat dari berhasil atau tidaknya tujuan instruksional khusus yang telah direncanakan dan dilaksanakan serta seberapa jauh target yang telah tercapai. Dimana semakin besar target yang dicapai maka semakin tinggi tingkat efektivitasnya.

\section{KESIMPULAN DAN SARAN}

\section{Kesimpulan}

Berdasarkan hasil penelitian dengan teknik observasi, wawancara dan dokumentasi yang dilaksanakan di kebun Batan Gading PT Satya Kisma Usaha tentang efektivitas pemupukan menggunakan pesawat dapat diambil beberapa kesimpulan. Kesimpulan tersebut dipaparkan sebagai berikut : (1) Efektivitas pemupukan menggunakan pesawat dari segi waktu adalah pemupukan yang relatif jauh lebih singkat dan lebih efektif yang mampu menyelesaikan pemupukan dengan jumlah ribuan ton dengan waktu paling lama 2 bulan dalam satu kali periode pemupukan. (2) Tepat cara dalam proses pemupukan menggunakan pesawat yaitu pupuk ditempatkan atau diaplikasikan di lapangan dengan cara menabur pupuk lewat udara melalui daun menggunakan pesawat sehingga pemberiannya jauh lebih merata dan efektif, dan dapat memberikan hara sesuai kebutuhan tanaman. (3) Tepat sasaran dalam pemupukan menggunakan pesawat yaitu pupuk yang diaplikasikan di lapangan diterima oleh tanaman serta tingkat penyerapannya jauh lebih tinggi serta tingkat kehilangan yang disebabkan faktor manusia dan faktor lainnya dapat teratasi sehingga pemupukan jauh lebih efektif serta hasil yang diperoleh jauh lebih maksimal.

\section{Saran}

Beberapa saran yang dapat temukan adalah :

(1) Perusahaan lebih mengembangkan strategi pemupukan menggunakan pesawat yang dapat membuat pemupukan jauh lebih efektif lagi terutama dalam persiapan areal landasan, sebaiknya areal landasan di aspal atau di cor sehingga diwaktu cuaca hujan jalan lintasan pesawat tidak licin, dan selang waktu pemupukan jauh lebih cepat. (2) Dalam proses pelaksanaan pemupukan menggunakan pesawe : pupuk yang disediakan di Bin adi $/ 0$ ton perhari, perusahaan sebaiknya menyediakan kapasitas yang lebih besar lagi sehingga stok pupuk yang berada di Bin menjadi lebih banyak dan pemupukan akan jauh lebih efektif lagi tanpa ada kendala kekurangan supply pupuk.

\section{DAFTAR PUSTAKA}

Departemen Pendidikan dan Kebudayaan, 1996. Kamus Besar Bahasa Indonesia. Balai Pustaka. Jakarta. 
Departemen pertanian, 2006. Potensi perkebunan kelapa sawit. Bumi aksara. Jakarta.

Direktorat Jenderal Perkebunan, 2016. Nilai strategis kelapa sawit. Penerbit Gramedia Utama. Jakarta

Direktorat Jendreral Perkebunan, 2016. Produksi lahan perkebunan kelapa sawit indonesia. Bumi aksara. Jakarta.

Fred R. David, 2006. Teknik Pengumpulan Data. $\quad$ http://repository.usu.ac.id. Diakses pada tanggal 16 Maret 2017. Lingga, 2002. Petunjuk Penggunaan Pupuk. Sinar Baru. Bandung.

Sinarmas Agribusiness Research and Teknologi,2003. pemeliharaan kelapa sawit. PT Rajawali Gravindo Persada. Jakarta. 